\title{
Tradisi Komunikasi Masyarakat Desa Kayu Elang dalam Kegiatan Pemilu
}

\section{Halbet Julianto}

\author{
Program Studi Magister Ilmu Komunikasi Pascasarjana Universitas Islam Bandung
}

Email: HalbetJulianto@yahoo.com

\begin{abstract}
The results of the study showed that: (1)Acts of communication on activities in the kayu Elang village has a meaning in accordance with the traditions inherited from their ancestors they hope for salvation, calm and smooth election activities from God the Almighty and the blessing of their ancestors. (2) communication situation that includes: $a$. Culture/cultural $b$. The ritual c.Community Formal, d. Trasedental, e.Local f. Paradoksal. (3) On communication events in the cultural aspects of selection activities/cultural, rituals, Formal, Trasedental, Local aims to smooth the election of the salvation of God the Almighty and the blessing of the spirit of their ancestors. There is a sequence of actions in the activities of the pre selection or election when the elections and post-election that has the meaning of each. In the event of communication there is also a focus of activities that the author of the link on the purpose of that will be achieved is to obtain salvation in the Lord God Almighty and the blessing of the parent of their ancestors so that the activities of the election went in accordance with their expectations. In the event of communication there is a message that comprise the codeverbaland non-verbal. Verbal code that is conveyed by the way of the oral: prayers, Becanang and greeting while on nonverbalnya message delivered in the form of a symbol or signals such as Sajian sajen, Kebung. Then there is the rule that made reference in the Kayu Elang culture. In the event of communication in the activities of the election there is a tradition of society in election activities that have been passed down from their generation to generation. 4). The process of communication tradition starts from a. Jago Dusun b. sedekah grave of ancestral c. pantang hari $d$. Making kebung e. Becanang $f$. Welcome speech g. Implementation of elections $h$. Penghanyutan pantang hari sedekah clossig job.
\end{abstract}

Keywords: Communication acts, Communication settings, Communication events, Communication process.

\begin{abstract}
Abstrak. Hasil penelitian menunjukkan bahwa: (1)Tindak komunikasi yang ada pada kegiatan pemilihan di Desa Kayu Elang mempunyai makna sesuai dengan tradisi yang diwariskan nenek moyang mereka mengharapkan keselamatan, ketentraman dan kelancaran kegiatan pemilihan dari Tuhan Yang Maha Kuasa dan restu dari leluhur mereka. (2)Situasi komunikasi yang meliputi: a. Budaya/kultural b. Ritual c.Formal, d. Trasedental, e.Lokal. f. Paradoksal. (3.) Pada peristiwa komunikasi dalam kegiatan Pemilihan aspek Budaya/kultural, Ritual, Formal, Trasedental, Lokal bertujuan untuk kelancaran pemilihan keselamatan dari Tuhan Yang Maha Kuasa, dan restu roh nenek moyang mereka. Terdapat Urutan tindakan dalam kegiatan pra pemilihan atau pemilu saat pemilihan, dan pasca Pemilihan yang mempunyai makna masing-masing. Pada peristiwa komunikasi terdapat juga fokus kegiatan yang penulis kaitkan pada tujuan yang akan hendak dicapai yaitu untuk mendapatkan keselamatan pada Tuhan Yang Maha Kuasa, restu dari leluhur moyang mereka agar kegiatan pemilihan berjalan sesuai dengan harapan mereka. Pada peristiwa komunikasi terdapat bentuk pesan yang terdiri kode verbal dan non verbal. Kode verbal yang disampaikan dengan cara lisan yaitu: doa-doa, becanang dan sambutan sedangkan pada pesan nonverbalnya disampaikan berupa simbol atau isyarat seperti sajian sajen, kebung. Selanjutnya terdapat kaidah yang dijadikan acuan dalam budaya Kayu Elang. Pada peristiwa komunikasi dalam Kegiatan pemilihan terdapat tradisi masyarakat dalam kegiatan pemilihan yang
\end{abstract}


telah diturunkan dari generasi nenek mereka sampai generasi sekarang. 4). Proses tradisi komunikasi dimulai dari a. Jago dusun b. Sedekah makam leluhur c. Pantang hari d. Pembuatan kebung e. Becanang $f$. Kata sambutan g. Pelaksanaan pemilihan h. Penghanyutan pantang hari i. Sedekah penutupan kerja.

Kata kunci : Tindak komunikasi, Setting komunikasi, Peristiwa komunikasi, Proses komunikasi.

\section{Pendahuluan}

Tradisi pemilihan di Desa Kayu Elang mempunyai keunikan tersendiri yang tidak dimiliki oleh tradisi pemilihan di desa lainnya. Tradisi pemilihan di Desa Kayu Elang mempunyai makna simbolis yang sangat lengkap didalamnya. Dalam proses pemilihan mereka memiliki aturan tersendiri dalam menjalankannya sesuai dengan adat kebiasaan dari lingkungan setempat. Berbagai persiapan disiapkan untuk menyambut kegiatan pemilihan. Persiapan ini dimulai dari kegiatan-kegiatan sebelum pemilihan maupun setelah pelaksanaan pemilihan. Berbagai kegiatan ini dilakukan sesuai dengan nilai budaya mereka. Nilai budaya itu tentunya diwariskan oleh nenek moyang mereka dalam menyambut suasana pemilihan yang berlangsung secara turun-temurun didesa mereka. Selain memiliki aturan dalam pemilihan terdapat juga tindakan komunikatif pada tradisi pemilihan seperti, ritual-ritual adat menyambut pemilihan yang tentunya mempunyai makna dan tujuan bagi masyarakat Desa Kayu Elang. Di era modern ini pemilihan atau dikenal dengan pemilihan umum masyarakat desa kayu elang masih menjalankan nilai-nilai budaya adat istiadat mereka setiap menghadapi proses pemilihan seperti tradisi ritual- ritual adat yang belangsung dari moyang mereka yang mempunyai tujuan tertentu bagi mereka.

Pentingnya Nilai budaya diwariskan pada generasi muda agar tidak kehilangan jejak budaya sendiri, apa lagi dengan era globalisasi dan makin terbukanya arus komunikasi dan informasi yang tidak terbatas akan membawa berbagai dampak baik yang positif maupun negatif dalam perkembangan kebudayaan, maka perlu segera pelestarian dan penggalian makna dari peninggalan budaya yang masih ada dalam hal ini khusus nya tradisi pemilihan di Desa Kayu Eang.

Penjelasan mengenai tradisi
pemilihan umum inilah yang
menguatkan peneliti r untuk
mengumpulkan data di lapangan.
Tradisi pemilihan umum Didesa Kayu Elang ini diyakini memiliki simbolsimbol komunikasi pada saat dilaksanakan dengan pola yang tersusun dan ritual-ritual yang dilakuan di Desa Kayu Elang tentunya sesuai dengan apa yang dipahami masyarakat kayu Elang .

Merujuk pada pembahasan di atas mengenai kebudayaan tentunya dapat dikaji dengan etnografi komunikasi. Dalam etnografi penelitian untuk mendeskripsikan kebudayaan sebagai mana adanya. Kegiatan pengumpulan bahan keterangan atau data yang dilakukan secara sistematik mengenai cara hidup serta berbagai aktivitas sosial dan berbagai benda kebudayaan dari masyarakat dan berbagai peristiwa dan kejadian unik dari komunitas kebudayaan.

Berdasarkan uraian tersebut penelitian ini menggunakan metode etnografi komunikasi dalam meneliti tradisi pemilihan umum di lingkungan masyarakat Desa Kayu Elang, sebagai aspek komunikasi yang merupakan fungsi komunikasi verbal maupun 
nonverbal pada kegiatan Pemilu mulai pra pelaksanaan Pemilu, saat Pemilu dan pasca pelaksanaan Pemilu dilingkungan masyarakat Desa Kayu Elang.

\section{Temuan dan Pembahasan}

Tindak komunikatif dalam analisis ini, penulis mengartikan tindak komunikatif sebagai suatu kegiatan yang menjadi akibat dari suatu kegiatan komunikatif Dalam kaitannya dengan kegiatan pemilihan di Desa Kayu Elang yang penulis jadikan masalah penelitian, tindak komunikatif berupa tindak partisipan suatu peristiwa komunikatif terhadap kegiatan komunikatif yang terjadi dalam kegiatan pemilihan.

Penulis menekankan pada rangkaian proses kegiatan pemilu di Desa Kayu Elang memberikan pola analisis yang berbeda dengan apa yang diungkapkan para ahli dalam penelitian etnografi komunikasi pada umumnya. Dalam tradisi kegiatan pemilihan ini setiap tindakan, ritual yang dilakukan sarat akan makna bagi mereka yang menjalankannya.

\section{Sedekah Pamitan di Makam Leluhur}

Kegiatan Ritual Sedekah termasuk pada tindakan komunikatif yang mempunyai sarat akan makna, adapun makna yang didapat dari kegiatan sedekah sebagai berikut:

1. Memohon kepada Tuhan Yang Maha Kuasa agar rencana kegiatan pemilihan atau pemilu mendapat ridho dan izinnya.

2. Agar diberikan keselamatan kepada semua yang terlibat dalam kegiatan pemilihan dari proses awal sampai selesai kegiatan.

3. Agar tidak ada gangguan roh jahat yang dapat memecah bela warga desa kayu Elang selama berlangsung nya kegiatan pemilihan

4. Sebagai bentuk penghormatan pada roh nenek moyang mereka yang diyakini mereka dapat mengganggu jalan nya kegiatan pemilihan apabila tidak berpamitan seperti keributan maupun perkelahian diantara warga.

\section{Pantang hari}

Kegiatan pantang hari termasuk pada tindakan komunikatif yang mempunyai sarat makna adapun makna dari kegiatan pantang hari sebagai berikut:

1. Memohon pada Tuhan Yang Maha Kuasa agar pada hari pelaksanaan pemilihan (pemilu) cuaca tidak hujan dan cuaca sejuk adem sehingga kegiatan berlangsung meriah dan warga desa yang bermukim di gunung berladang bisa pulang melaksanakan pemilihan.

2. Diharapkan banyak masyarakat yang melakukan pemilihan dan mengurangi golput

\section{Pembuatan Kebung}

Pembuatan kebung adalah termasuk pada rangkaian kegiatan pemilihan. Pembuatan kebung ini mereka lakukan di tempat terbuka yang dapat disaksikan oleh masyarakat banyak. Tujuan dari pada pembuatan kebung ini adalah agar masyarakat bersama-sama mengawasi kegiatan pemilihan supaya tidak ada pihak-pihak yang ingin melakukan kecurangan.

Adapun Makna dari pembuatan kebung di area terbuka ini sebagai :

1. Agar kegiatan pemilihan terlihat meriah disaksikan banyak masyarakat 
2. Menanamkan

nilai-nilai kejujuran

3. Tidak ada kecurangan setiap ada kegiatan pemilihan

\section{Becanang (pengumuman dusun)}

Kegiatan becanang ini disampaikan secara lisan kepada warga masyarakat dengan cara diteriakkan dengan berkeliling desa. kegiatan becanang dimana kegiatan ini termasuk kedalam tindak komunikatif yang dimaknai sebagai ajakan kepada warga untuk memilih, memeriahkan dan menonton jalannya kegiatan saat pemilihan. kegiatan becanang ini dilakukan oleh seorang juru aman desa ( hansip) yang langsung diperintah oleh kepala desa. Becanang dilakukan pada waktu sore diasumsikan jika melakukan canangan pada saat sore hari menjelang petang, masyarakat akan banyak mendengar canangan yang disampaikan, sebab kalau waktu sudah sore mejelang petang masyarakat sudah banyak beristirahat dirumah.

\section{Sambutan}

Kata Sambutan yang dilakukan oleh kepala desa termasuk dalam tindakan komunikatif yang disampai dalam bentuk lisan yang mengandung makna ajakan damai kepada seluruh warga Desa Kayu Elang.

\section{Penghanyutan Pantang Hari}

Kegiatan penghanyutan pantang hari ini termasuk pada tindakan komunikatif yang berisi do,a- do'a yang bermakna permohonan kepada Yang Maha Kuasa agar cuaca kembali pada keadaan seperti biasanya. Kegiatan hanya dilakukan oleh seorang kuncen dengan melakukan ritual mandi dengan membaca doa-doa.

\section{Sedekah Penutupan Kerjo}

Sedekah penutupan Sedekah penutupan kerjo termasuk pada tindakan komunikatif yang mempunyai makna sebagai berikut:

1. Menyampaikan ucapan terimakasih pada Tuhan yang Maha Kuasa dan leluhur mereka bahwa kegiatan pemilihan telah dilakukan. Setelah itu masyarakat akan menjalankan kegiatan mereka seperti biasanya tanpa ada gangguan dan seterusnya berkaitan dengan suasana pemilihan atau pemilu yang akan datang.

2. Agar tidak ada dendam dan perselisihan diantara anak cucu mereka yang masih hidup

Dalam penelitian ini komunikasi yang dimaksud adalah interaksi yang terjadi dalam bentuk suasana yang cair, bukan percakapan melainkan rangkaian tradisi kegiatan pra pemilu, saat pemilu dan pasca pemilu di Desa Kayu Elang.

Kegiatan pemilu tidak asing lagi didengar ditelinga. Sebelumnya tradisi pemilihan sudah dilakukan pada masyarakat Desa Kayu Elang dari jaman dahulu seperti pemilihan (depati) atau dalam istilah sekarang pemilihan Kepala Desa. Seiring dengan jaman demokrasi saat ini, Desa Kayu Elang juga ikut andil dalam kegiatan Pemilihan Umum. Sebagai sebuah tradisi, adanya kegiatan-kegiatan yang mengakar dilingkungan desa Kayu Elang. Kegiatan ini apabila dikaitkan pada teori interaksi simbolik terdapat ada tindakan-tindakan di lingkungan masyarakat Desa Kayu Elang yang mempunyai makna. Seperti sedekah minta keselamatan atau keamanan atau pamitan ketempat puyang (makam keramat atau leluhur mereka yang diyakini masyarakat setempat, bacanang, pembuatan kebung dilapangan atau tempat lahan terbuka, pantang hari (sedekah tolak hujan). 
Apabila dikaitkan pada setting dalam situasi komunikasi kegiatan pemilu di Desa Kayu elang, sesuai dengan rangkaian dan tahapan pemilu pada umumnya dimana dilaksanakan dimulai jam 07.00 sampai jam 13.00 kegiatan nya belangsung hanya dalam satu hari. Tetapi, sebelum hari pelakasanaan pemilu ada berbagai kegiatan budaya yang dilakukan.

Dalam menjalankan kegiatan pemilihan umum masyarakat desa Kayu elang tidak telepas dari kebudayaan mereka seperti (sedekah kerumah puyang) kegiatan ini meminta selamatan di makam puyang leluhur mereka, agar selama kegiatan pemilu tidak terjadi hal-hal buruk seperti keributan antar sesama penduduk setempat, baik warga biasa atau warga pendukung calon tertentu. Sebab suasana pemilu dianggap berpotensi menimbulkan konflik dan permusuhan sesama warga. Kegiatan ini dilakukan oleh perangkat desa, tua adat, kuncen dan warga setempat.

Mendekati hari pemilu tiba terdapat banyak keunikan dalam tradisi masyarakat desa kayu Elang seperti jago dusun yang melibatkan semua warga desa Kayu elang. Jago dusun sama seperti yang dilakukan penjagaan ronda pada umumnya. Di desa kayu elang melakukan jago dusun bergilir pada setiap kepala keluarga. Kegiatan jago dusun mempunyai tujuan tersendiri bagi mereka. Selain untuk keamanan selama kegiatan pemilu juga diharapkan tidak ada kasus kriminal yang dapat mengganggu masyarakat setempat dan dapat merugikan masyarakat secara materil atau non materil. Begitu juga sedekah di makam leluhur yang dimaknai sebagai doa meminta selamatan dan pamitan pada leluhur mereka dan pantang hari yang diartikan meminta tidak diturunkan nya hujan pada saat pelaksanan pemilihan.
Ada juga kegiatan becanang,
yang dapat pengumuman, bercanang disini dimana seorang warga yang telah dipercaya warga melakukan kegiatan semacam pengumuman pada warga setempat mengenai waktu pemilu dan tempat dilakukan pemilu. Dimana orang bersangkutan keliling kampung sambil meneriakkan pengumuman pemilihan dan tempat lokasi pemilihan.

Situasi komunikasi pada kegiatan pemilu dilakukan pada lokasi lapangan terbuka, bertujuan untuk situasi Pemilihan yang tertib, meriah, terbuka diasumsikan nilai kejujurannya tinggi dan tidak ada kecurangan.

Berikut ini temuan penulis dapatkan berkaitan dengan situasi komunikasi pada saat tradisi Pemilihan di Desa Kayu Elang:

\section{Kultural}

Kegiatan Pemilihan melibatkan unsur budaya dalam berbagai bentuknya di setiap tahapan tradisi pemilihan. Adat istiadat, kebiasaan ,tempat, ruang, pemilihan waktu, dan kepercayaan yang telah diwariskan secara turun temurun yang menjadi pakem bagi melangsungkan kegiatan pemilihan. Budaya yang ditampilkan merupakan budaya serawai.

\section{Ritual}

Dalam rangkaian pemilihan melibatkan berbagai ritual, dari pra pemilihan-pasca pemilihan . Setiap ritual yang dilakukan menandai pelaksanaan masing-masing tahap kegiatan. semuanya menggunakan berbagai benda dan cara khusus sesuai dengan ritual yang dilakukan. Ritual sedekah kerumah puyang membawa perlangkapan sesajen, ritual pantang hari juga menggunakan sesajen dan penutupan kerjo menggunakan sajen. 
3. Kegiatan formal

Kegiatan Pemilihan dilakukan secara formal, mengingat acara ini melibatkan Pemerintahan Desa dilakukan secara formal dengan pakempakem yang telah ditentukan. Tahapantahapan pada kegiatan pemilihan diikuti oleh Kepala Desa dan perangkatnya, tua adat, kuncen, dan warga.

\section{Trasedental}

Hampir setiap tahapan sedekah berisikan permohonan-permohonan yang mengandung kebaikan, permintaan, kepada Tuhan Yang Maha Kuasa. Seperti sedekah di rumah puyang yang diekspresikan dalam bentuk upacara keselamatan walaupun kegiatan sedekah itu melibatkan unsur mistis dan magis misalnya membawa sesajen dan pembakaran kemenyan sebagai media komunikasi kepada Tuhan Yang Maha Kuasa dan pembawa berita pada ruamelikat (roh) leluhur mereka.

Membawa sesajen ke makam keramat atau leluhur setempat dan ritual do'a- do'a mengandung arti meminta keselamatan, keamanan dan ketertiban sehingga kegiatan pemilihan atau pemilu berjalan sesuai dengan yang diharapkan.

\section{Lokal}

Lokal, yang dimaksud adalah terkait dengan lokasi penyelenggaraan yaitu wilayah lokal. Para pendukung kegiatan hanya diikuti masyarakat lokal dari wilayah Desa Kayu Elang. Tradisi kegiatan pemilihan mulai pra pemilihan sampai setelah pemilihan dilangsungkan di lingkungan Desa Kayu Elang. Semua Kegiatan melibatkan masyarakat lokal baik sebagai pelaku pemilihan maupun yang terlibat dalam panitia pemilihan dan penyelenggaraan ritual.

\section{Paradoksal}

Terdapat aspek-aspek yang bertolak belakang dan saling berbenturan dengan sebagian masyarakat Desa. Kegiatan ritual-ritual sedekah memiliki karakteristik paradoksal. Karena masyarakat desa sudah jelas mayoritas beragama islam tetapi masih melakukan kepercyaankepercayaan masa lalu. Pemberian sesajen, pembakaran kemenyan meski dimaknai sebagai komunikasi mereka dengan yang maha kuasa dan leluhur mereka, sesungguhnya berbenturan dengan ajaran islam itu sendiri.

Kegiatan pemilu dilakukan di Desa Kayu Elang tentunya tidak terlepas dari kebiasaan adat mereka. Selanjutnya penulis menganalisa peristiwa komunikasi yang mengacu pada komponen-komponen peristiwa komunikasi seperti yang dikemukakan Hymes terdapat delapan komponen peristiwa komunikasi. Tentunya akan penulis analisa satu-persatu dari delapan komponen peristiwa komunikasi tersebut.

Komponen pertama peristiwa komunikasi adalah setting. Setting yang terdapat dalam tradisi pemilihan umum dimana dimulainya dari awal kegiatan pemilu sampai akhir kegiatan pemilu, setting yang akan penulis paparkan sama hal nya dengan situasi komunikasi yang telah penulis jelaskan sebelumnya. Atau Dimana terdapat situasi komunikasi budaya atau kultural, kegiatan formal, kegiatan ritual, kegiatan trasedental, lokal dan paradoksal.

Dari analisis ini tentunya penulis memaparkan siapa saja yang terlibat dalam komunikasi dalam kegiatan pemilu dimulai dari awal sampai berakhirnya kegiatan pemilu di Desa Kayu Elang. Dalam kegiatan pemilu terdapat partisipan antara lain kepala Desa selaku pemerintahan desa 
setempat, sesepuh desa selaku orang yang dituakan di desa setempat, juru kuncen tempat leluhur atau keramat, dan masyarakat desa Kayu elang.

Dalam kegiatan pra pemilihan peran kepala desa dan sesepuh desa tentunya mempunyai peran kekuasaan penuh didalam desanya begitu juga peran juri kunci keramat mereka melakukan ritual sesajen sebagai komunikasi mereka agar diberi kenyamanan, jauh dari keributan, sehingga pemilu berjalan dengan sesuai harapan mereka. Selanjutnya partisipan warga desa kayu elang dimana mereka terlibat langsung dalam kegiatan pemilu.

Pada komponen ke dua dari peristiwa komunikasi adalah Ends. Ends atau tujuan dari proses komunikasi dengan berbagai kegiatan dan ritual adalah tercapainya kegiatan pemilu di Desa Kayu Elang dimulai dari suasana awal kegiatan sampai akhir pemilu tanpa ada keributan, kekacauan maupun kerugian harta benda

Tujuan yang hendak dicapai dari berbagai kegiatan pemilu adalah kelancaran proses pemilihan atau pemilu, keselamatan dari Tuhan Yang Maha Kuasa, dan restu roh nenek moyang mereka.

Pada komponen ke tiga dalam peristiwa komunikasi adalah act sequence (urutan tindakan). Urutan tindakan ini merupakan isi pesan yang akan dikomunikasikan dan bagaimana cara mengkomunikasikannya.

Berikut ini adalah urutan tindakan dalam kegiatan pemilu di Desa Kayu Elang :

1. Kepala desa menunjuk dari kalangan warga untuk menjadi panitia yang akan mengurusi kegiatan pemilu atau sering disebut ( tim PPS (Panitia Pemungutan Suara)).

2. Kepala Desa memerintahkan jago dusun 2 minggu sebelum kegiatan hari pemilu dan 1 minggu setelah kegiatan pemilu dengan tujuan keamanan karena kegiatan pemilihan rawan akan konflik.

3. Kepala Desa melakukan komunikasi pada perangkat desa , sesepuh desa, tua adat, masyarakat luas.

4. Kepala Desa, sesepuh Desa, tua adat, warga seminggu sebelum kegiatan pemilihan melakukan pamitan dengan cara membawa sesajen kepada makam leluhur mereka tujuannya meminta keselamatan, ketentraman, jauh dari keributan kepada Tuhan Yang Maha Kuasa..

5. Sehari sebelum pelaksanaan pemilihan tim PPS dibantu perangkat desa melakukan pembuatan kebung.

6. Sehari sebelum kegiatan pemilu tepat nya pada sore sebelum pelaksanaan pemilihan ada kegiatan (becanang), dimana kegiatan (becanang) ini semacam pengumuman desa dimana seseorang perangkat Desa memberitahukan dan memastikan kegiatan pemilu dilaksanakan di tempat mana dan jam pelaksanaannya kepada masyarakat Desa Kayu Elang. Kegiatan becanang ini tetap dilaksanakan meskipun surat undangan pemilihan suara sudah dibagikan.

7. Sehari menjelang hari pemilihan atau pemilu diadakan kegiatan ritual dimana seseorang juru doa sajen melakukan kegiatan (pantang hari). Pantang hari ini dengan tujuan agar pada saat kegiatan pemilu tidak berlangsungnya hujan sehingga kegiatan pemilunya dapat berjalan dengan hikmat dan warga masyarakat yang 
bermukim di perkebunan dapat pulang kedesa untuk melakukan pemilihan.

8. Pada hari pemilu dilakukan di tanah lapangan. Tujuannya agar tidak ada kecurangan dan dapat disaksikan masyarakat luas.hal ini dilakukan setiap gelaran pemilu dari dahulu (pemilihan Kepala Desa, Kepala daerah dan pemilihan lainnya).

9. Kepala memberikan kata sambutan berupa arahan dengan tujuan mengajak masyarakat tertib dan tim pendukung calon pemenangan agar tidak terjadi keributan.

10. Masyarakat melakukan pencoblosan

11. Selesai pemilihan,sehari setelah pelaksanaan pemilihan juru kuncen pantang hari melakukan kegiatan penghanyutan pantang hari dengan melakukan kegiatan mandi

12. Seminggu setelah pelaksanaan pemilihan Kepala Desa Perangkat desa, tua adat dan juru kuncen melakukan ritual penutupan kerjo di makam leluhur mereka dengan membawa perlengkapan sajen menyampaikan ucpan terima kasih pada Tuhan Yang Maha Kuasa dan leluhur mereka

Pada urutan tindakan diatas mempunyai makna sesuai dengan kegiatan masing-masing.

Pada komponen fokus (keys) dalam kegiatan pemilihan umum tentunya penulis kaitkan pada tujuan yang akan hendak dicapai yaitu untuk mendapatkan keselamatan pada Allah dan kegiatan pemilih berjalan seseuai dengan apa yang diharapkan yaitu aman,jujur dan jauh dari perselisihan antar warga.

Pada komponen berikutnya tentang (instrumentalitis) dimana akan membahas bentuk pesan. Dalam bentuk pesan ini terdiri dari kode verbal dan nonverbal. Tentunya pesan verbal yang dimaksud adalah pesan yang disampaikan dengan cara lisan sedangkan pesan nonverbal adalah pesan yang disampaikan berupa simbol atau isyarat.

Dalam penelitian yang penulis ketahui kode verbal yang terdapat dalam kegiatan pemilu di Desa Kayu Elang adalah do'a - do'a, becanang, kata sambutan. Pembacaan do'a dalam kegiatan pamitan dengan sesajen diucapkan dengan lisan.

Pada kode nonverbal seperti sesajen, kebung (tempat pemilihan berlangsung), gambar atau foto, alat coblos. Tentunya kode ini sebagai kode nonverbal, karena kode noverbal ini menjadi intrumentalitis yang menunjuk adanya simbol-simbol yang sarat akan makna dalam pelaksanaan kegiatan pemilu.

Pada norma-noma interaksi (norm of interaction) merupakan suatu kaidah-kaidah yang telah menjadi acuan dalam budaya dalam hal pelaksanaa pemilihan.

Pada kegiatan pemilu di Desa Kayu Elang terdapat kaidah interaksi dalam kegiatan pemilu yang dilakukan dari nenek moyang di Desa mereka terdahulu. Kaidah ini menjadi norma dimasyarakat setempat sehingga menjadi kepercayaan masyarakat setempat untuk mendapatkan keselamatan, jauh dari keributan terutama pada sesama warga desa kayu Elang dimana setiap kegiatan pemiihan (pemilihan kepala desa, kepala daerah) suasananya rawan akan konflik sesama warga. Apabila tidak dilaksanakan seperti ritual-ritual pada makam keramat leluhur mereka ditakutkan akan terjadi keributan pada pelaksanaan pemilihan.

Pada genre, dilihat dari permasalahan yang penulis angkat, 
kegiatan sedekah, becanang, pantang hari sudah jelas merupakan tradisi pemilihan. Disamping mengedepankan aturan dalam undang-undang pemilu yang diatur pemerintah, taradisi khas tetap dilakukan setiap kegiatan akbar pemilihan.

Kepala Desa memerintahkan Linmas untuk menyampaikan ajakan secara langsung dengan mendatangi masing-masing rumah penduduk, jago dusun adalah kegiatan ronda malam untuk menjaga desa.. kegiatan ini dilaksanakan dua minggu sebelum pelaksanaan hari pemilihan. Jago dusun ini merupakan ronda malam yang dilakukan oleh kepala keluarga dengan cara bergiliran perkelompok kepala keluarga. Menurut Blumer masyarakat terdiri dari manusia yang berinteraksi, kegiatan tersebut saling bersesuaian melalui tindakan bersama.

Setelah itu kepala desa dan juru kuncen secara bersama-sama melakukan Sedekah Pamitan di makam leluhur puyang adalah ritual membawa perlengkapan sesajen ke makam leluhur puyang. Sedekah dihadiri tua adat dan sebagian masyarakat desa. Sedekah bermakna pamitan dan memohon keselamatan pada Tuhan Yang Maha Kuasa. Pembakaran kemenyan dan doadoa diawali dengan pengolesan minyak oleh perwakilan perangkat desa pada batu-batu dan meriam.Meletakkan perlengkapan Sajen yang telah dibuat sebelumnya, duah buah nasi jambar (tumpeng) kecil berisi telur ayam belantan ( putih), bakul batera yang di isi cangkir berisi (pedas (cabe) dan garam, benang woll, jarum,belacu (kain) putih ), sirih, kapur, buah pinang, air.Juru kuncen yang didampingi oleh kepala Desa, tua adat dan warga melakukan ritual pembakaran kemenyan dan sesajian yang dihidangkan dimaknai simbol penyampaian pesan pada para leluhur bahwa akan ada rencana besar yang akan dilakukan di desa tersebut. Sesaji yang dihidangkan menjadi sebuah simbol agar semua kegiatan berjalan dengan lancar. Melalui sesaji ini dimaksudkan sebagai media komunikasi mereka yang masih hidup dengan yang Kuasa dan leluhur mereka. Tindakan membawa sesajen diyakini mempunyai makna membawa keselamatan bagi masyarakat setempat. Menurut (Sihabudin 2011:73-74). Asumsi dasar interaksi simbolik adalah manusia mampu menciptakan simbol-simbol mempergunakannya. Sejalan dengan pendapat Mulyana (2003: 71) menjelaskan bahwa manusia tertarik menggunakan simbol-simbol yang mempresentasikan apa yang mereka maksudkan untuk berkomunikasi dengan sesama, dan juga pengaruh yang ditimbulkan penafsiran atas simbolsimbol. Sesajen disimbolkan masyarakat sebagai perantara untuk berkomunikasi pada leluhur mereka. Sesajen yang mereka hidangkan diasumsikan sebagai media komunikasi mereka pada leluhur dan Tuhan Yang Maha Kuasa. Begitu juga dengan sesajen yang digunakan pada kegiatan pantang hari. Pembakaran kemenyan dan perlengkapan sajian sebagai media komunikasi mereka dalam memohon pada Tuhan Yang Maha Kuasa dan leluhur mereka.

Pembuatan kebung adalah pembuatan tempat pemilihan. Pembuatan kebung ini menggunakan perlengkapan dari bambu dan tenda. Sejak jaman dahulu kebung dibuat diarea terbuka seperti dilapangan. Pembuatan kebung diarea terbuka dimaknai masyarakat sebagai menjunjung tinggi nilai kejujuran. Dengan menginterpretasikan pembuatan kebung di area terbuka sebagai nilai kejujuran dalam politik. Maka secara langsung mengajarkan pada masyarakat perilaku kejujuran dalam pemilihan. 
Sejalan dengan pendapat (Sihabudin, 2011:73-74) "jika simbol-simbol yang diberikan oleh pihak lain seseorang individu akan berperilaku tertentu sebagai tanggapan terhadap adanya simbol-simbol yang diterima”. Sejalan dengan penelitian ini dengan menginterpretasikan kebung sebagai simbol kejujuran dan keterbukaan maka warga masyarakat akan berperilaku jujur dalam kegiatan pemilihan.

Dalam kegiatan becanang atau pengumuman dusun yang diumumkan oleh juru aman desa (hansip) atas perintah Kepala Desa yang dilakukan sehari sebelum pelaksanaan pemilihan yang bertujuan mengajak warga Desa untuk memilih (mencoblos), menonton maupun menyaksikan acara pemilihan, kegiatan becanang adalah tradisi turun temurun oleh nenek moyang mereka sejak jaman dahulu yang berisikan pengumuman atau ajakan kepada masyarakat desa yang dilakukan dengan cara berkeliling desa dengan berteriakteriak menyampaikan ajakan. Menyampaikan pengumuman dengan cara berteriak sambil keliling dusun dengan bahasa daerah ditafsirkan masyarakat sebagai kegiatan becanang. Sejalan dengan pendapat Blumer (dalam Basrowi, 2002:139) "interaksi simbolik terdiri dari berbagai kegiatan manusia yang berhubungan dengan kegiatan manusia. Interaksi simbolik mencakup penafsiran tindakan. Bahasa merupakan simbol yang paling umum berlaku di masyarakat". Becanang merupakan kegiatan interaksi dengan menggunakan bahasa daerah setempat.

Pada pelaksanaan pemilihan terlebih dahulu dibuka dengan kata sambutan oleh Kepala Desa. Proses pemungutan suara ini berlangsung menggunakan alat- alat peraga pemilu dari KPU. Proses pencoblosan suara sepenuhnya diselenggarakan oleh PPS setempat dengan mengikuti aturanaturan yang telah ditetapkan oleh
KPUD. pemilihan dan lainnya. Setelah melakukan kegiatan pemilihan didapati kegiatan penghanyutan pantang hari dan sedekah penutupan kerjo. Sedekah penutupan kerjo dilakukan di makam keramat leluhur mereka yaitu makam kepuyangan. Sedekah penutupan kerjo ini dilakukan dengan makna memberikan ucapan terimah kasih pada Yang Kuasa dan leluhur mereka

Berbicara kegiatan adat tentunya tidak terlepas dari sebuah bentuk kebudayaan atau juga adat istiadat yang sering dilakukan oleh suatu kumpulan masyarakat di suatu daerah tertentu yang memiliki suatu adat istiadat yang harus dapat di pertahankan secara turuntemurun, karena dapat dikatakan bahwa kebudayaan atau istiadat yang dimiliki oleh suatu masyarakat di daerah tertentu merupakan sebuah warisan dari para leluhur yang harus dipertahankan sampai seterusnya. Ritual adat itu sendiri adalah suatu bentuk kegiataan yang berhubungan dengan kebudayaan atau adat-istiadat yang sering dilakukan oleh suatu anggota masyarakat yang ada di daerah tertentu, dapat dikatakan juga merupakan sebuah tradisi yang selalu dilakukan secara turun-temurun atau juga merupakan warisan kebudayaan dari para leluhur yang harus dapat dipertahankan, dan juga merupakan kebiasaan yang sering dilakukan oleh kelompok masyarakat tertentu yang ada disuatu daerah, yang memiliki aturan, dan nilai yang sangat sakral yang harus dijunjung dan apabila melanggarnya dengan sendirinya akan mendapat sanksi.

Kegiatan pemilihan bukan hanya sekedar untuk memilih pasangan calon kepala daerah. Terdapat ada banyak sareamoni dilakukan oleh warga Desa Kayu Elang. Yang mana, kegiatan pemilihan tersebut melibatkan berbagai dimensi komunikasi yang sangat khas dan penuh makna. 
Setiap kegiatan pemilihan mayarakat Kayu Elang tidak terlepas dari kegiatan- kegiatan adat, bagi masyarakat Desa Kayu Elang setiap kegiatan yang telah diwariskan nenek moyang mereka harus dilaksanakan. Seperti sedekah pamitan ke makam leluhur merupakan ketentuan nenek moyang mereka yang harus di taati, agar terhindar dari hal-hal buruk yang terjadi dikalangan masyarakat Desa Kayu Elang. Dalam melakukan ritual sedekah di makam leluhur mereka selalu diiringi dengan doa-doa dan sajian sajen yang dibuat sesuai dengan adat istiadat mereka. Sajian sajen diasumsikan perantara penghubung bagi mereka yang masih hidup dengan leluhur. Ritual sedekah dirumah leluhur dimaknai mereka sebagai permohonan selamatan pada Tuhan dan pamitan bagi mereka yang masih hidup kepada roh leluhur mereka. Begitu juga pada ritual penutupan kerjo dilakukan dengan doadoa dan membawa sajen. Ritual -ritual ini dilakukan sebagai penghubung kepada Tuhan dan roh leluhur mereka.

Seperti yang diketahui asumsi interaksi simbolik yaitu manusia bertindak terhadap sesuatu berdasarkan makna-makna yang ada pada sesuatu itu bagi mereka, makna diperoleh dari hasil interaksi sosial yang dilakukan oleh orang lain, makna -makna tersebut disempurnakan di saat proses interaksi sosial sedang berlangsung ( Blumer dalam Basrowi, 2002;136)

Kegiatan jago dusun, sedekah , pantang hari, becanang adalah kegiatan yang diwariskan dari nenek moyang mereka melalui hasil interaksi. Melalui interaksi inilah budaya mereka dapat diwariskan

Dari berbagai kegiatan yang dilakukan dimulai dari pra pemilihan, pelaksanaan pemilihan dan pasca pemilihan terdapat bentuk pesan, bentuk pesan ini terdiri dari kode verbal dan nonverbal. Pesan verbal yang dimaksud adalah pesan yang disampaikan dengan cara lisan sedangkan pesan nonverbal adalah pesan yang disampaikan berupa simbol atau isyarat.

Dalam analisa yang telah dilakukan penulis terdapat kode verbal dalam kegiatan pemilu di Desa Kayu Elang seperti do'a - do'a, becanang, kata sambutan. Pembacaan do'a sedekah dengan membawa sesajian dalam kegiatan pamitan diucapkan dengan bahasa lisan. Do'a-doa sedekah, becanang, kata sambutan disampaikan melalui bahasa dengan kalimat yang sarat mengandung makna. Seperti menurut Cangara (2007:99) bahwa bahasa dapat diartikan sebagai seperangkat kata yang telah disusun secara terstruktur sehingga menjadi kalimat yang mengandung kalimat yang mengandung makna.

Seperti yang terdapat dalam do'a- doa ritual yng disampaikan pada saat sedekah yang mengandung makna meminta selamat kepada Tuhan Yang Maha Kuasa dan pamitan pada leluhur mereka. Begitu juga dengan becanang adalah pengumuman dusun yang bermakna sebagai ajakan untuk melakukan pemilihan.

Pada kode nonverbal penulis mendapatkan seperti sesajen, kebung (tempat pemilihan berlangsung). Kode ini sebagai kode nonverbal, karena kode noverbal ini menjadi intrumentalitis yang menunjuk adanya simbol-simbol yang sarat akan makna dalam pelaksanaan kegiatan pemilihan. Komunikasi non verbal ini disampaikan dengan tidak menggunakan kata-kata, hal ini sejalan dengan apa yang disampaikan Suranto (2010:153) bahwa komunkasi verbal adalah komunikasi yang menggunakan pesan-pesan non verbal, non verbal disini adalah komunikasi diluar katakata terucap atau tertulis.

Pembuatan kebung yang dibuat di areal terbuka bukan hanya sebatas 
untuk dapat menampung masyarakat banyak, pembuatan kebung diareal terbuka dimaknai sebagai bentuk kejujuran, transparansi bagi masyarakat Kayu elang. Ini tetap dijalankan setiap ada kegiatan pemilihan

Dalam melakukan kegiatan pemilihan baik pra penelitian, pelaksanaan penelitian dan pasca penelitian. Pesan dikemas dalam bahasa dan bentuk yang mudah dipahami oleh semua elemen masyarakat dan memiliki identitas sendiri, dimana bahasa disampaikan dalam bentuk bahasa lokal seperti dalam Kegiatan becanang, do'adoa dan sambutan. Pada temuan peneliti di lapangan cara yang dilakukan oleh kepala Desa, perangkat desa, tua adat, kuncen dan warga dalam menjaga warisan leluhur mereka. Tidak hanya menjaga warisan leluhur mereka, kegiatan tradisi pemilihan tetap dilakukan guna untuk keselamatan dan kelancaran kegiatan pemilihan.

$$
\text { Mulyana (2003: }
$$

menjelaskan bahwa manusia tertarik menggunakan simbol-simbol yang mempresentasikan apa yang mereka maksudkan untuk berkomunikasi dengan sesama, dan juga pengaruh yang ditimbulkan penafsiran atas simbolsimbol, manusia dapat memunculkan penafsiran yang berbeda-beda terhadap pernyataan manusia. Sehingga menimbulkan interaksi khusus antar manusia.

Sejalan dengan temuan penulis dilapangan para Kepala Desa, perangkat desa, tua adat, kuncen, juru aman dusun menggunakan bahasa daerah atau lokal. Apa yang mereka lakukan selalu menggunakan simbol daerah. Dalam melakukan ritual kuncen akan merasa nyaman dengan masyarakat dan leluhur mereka apabila menggunakan bahasa daerah dengan berbagai pemaknaannya.

Bila dikaitkan dengan interaksi simbolik setiap tindakan yang dipilih oleh kepala desa, perangkat desa, tua adat, kuncen, warga desa dan lainnya, memiliki makna. Apabila dikaitkan dengan situasi penelitian ini, tindakan memilih tempat melaksanakan kegiatan sedekah di makam puyang dan pembuatan kebung di area lapangan terbuka sebagaimana sarat dengan makna. Hal ini bukan sekedar dimaknai sebagai ruang atau tempat terbuka yang digunakan sebagai tempat menampung banyak orang. Tetapi tindakan ini menyiratkan kepatuhan pada warisan nenek moyang mereka yang dimaknai sebagai wujud ikatan keluarga besar masyarakat desa kayu elang dengan leluhur mereka.

Dalam melakukan ritual sedekah selalu diiringi dengan pembakaran kemenyan didalam dupa. Pembakaran kemenyan sebagai wangi-wangian yang ditujukan untuk menghadap leluhur mereka. sejalan dengan apa yang dikemukakan Leather dalam (Rakhmat 2012;289-290) yang mengatakan pesan nonverbal nonvisual meliputi tidak berupa kata-kata, tidak terlihat, dan tidak terdengar, dan meliputi sentuhan dan penciuman.

\section{Simpulan dan Saran}

Berdasarkan hasil penelitian yang telah penulis lakukan tentang kegiatan Pemilihan atau Pemilu di Desa Kayu Elang, penulis melakukan kesimpulan sebagai berikut:

1. Tindak komunikasi yang ada pada kegiatan pemilihan atau Pemilu di Desa Kayu Elang tentunya mempunyai makna sesuai dengan tradisi yang diwariskan nenek moyang mereka. Tindakan komunikasi pada rangkaian pra pemilihan dimulai dari acara sedekah makam leluhur sampai sedekah penutupan kerjo mengharapkan keselamatan, ketentraman dan kelancaran kegiatan pemilihan dari Tuhan Yang Maha Kuasa 
dan restu dari leluhur mereka. Sajian sajen pun sarat akan makna dan sebagai pehubung antara yang mereka dengan leluhur mereka.

2. Situasi komunikasi yang meliputi:

a. Budaya/kultural, dalam kegiatan pemilihan atau Pemilu ini melibatkan unsur budaya yang dijalankan sesuai, adat,kebiasaan, kepercayaan warga yang telah diwariskan sebelumnya.

b. Ritual, dalam kegiatan Pemilihan atau Pemilu melibatkan berbagai ritual,terutama pada kegiatan sedekah kemakam puyang, pantang hari, penghanyutan pantang hari dan sedekah penutupan kerjo.

c. Formal, dalam kegiatan Pemilihan di desa melibatkan pihak Kepala Desa, Perangkat Desa, Tua adat, Kuncen,

d. Trasedental, adanya ritual yang berisikan permohonanpermohonan yang mengandung kebaikan,permintaan pada Tuhan Yang Maha Kuasa, dan pamitan pada leluhur mereka.

e. Lokal, lokasi pelaksanaan terdapat di lingkungan Desa Kayu Elang dan hanya diikuti masyarakat Desa Kayu Elang

f. Paradoksal, Terdapat aspekaspek yang bertolak belakang dan saling berbenturan dengan sebagian masyarakat Desa. Pemberian sesajen, pembakaran kemenyan meski dimaknai sebagai komunikasi mereka dengan yang maha kuasa dan leluhur mereka, sesungguhnya berbenturan dengan ajaran islam itu sendiri.

3. Pada peristiwa komunikasi dalam kegiatan Pemilihan di Desa Kayu Elang terdapat aspek Budaya/kultural, Ritual, Formal, Trasedental, Lokal yang bertujuan yaitu untuk kelancaran pemilihan atau pemilu, keselamatan dari Tuhan Yang Maha Kuasa, dan restu roh nenek moyang mereka. Terdapat Urutan tindakan dalam kegiatan pra pemilihan atau pemilu saat pemilihan, dan pasca Pemilihan yang mempunyai makna masing-masing. Pada peristiwa komunikasi terdapat juga fokus kegiatan yang penulis kaitkan pada tujuan yang akan hendak dicapai yaitu untuk mendapatkan keselamatan pada Tuhan Yang Maha Kuasa, restu dari leluhur moyang mereka agar kegiatan pemilihan berjalan sesuai dengan harapan mereka.

Pada peristiwa komunikasi dalam kegiatan pemilihan terdapat bentuk pesan yang terdiri kode verbal dan non verbal. Kode verbal yang disampaikan dengan cara lisan yaitu: doa-doa, becanang dan sambutan sedangkan pada pesan nonverbalnya disampaikan berupa simbol atau isyarat seperti sajian sajen, kebung.

Pada peristiwa komunikasi terdapat kaidah yang dijadikan pakem dan acuan dalam budaya Kayu Elang. Kegiatan pemilihan merupakan tradisi masyarakat dalam kegiatan pemilihan atau Pemilu yang telah diturunkan dari generasi nenek mereka sampai generasi sekarang.

Berdasarkan penelitian yang dilakukan, peneliti mengajukan saran- 
saran, baik rekomendasi secara teoritis mapun praktis yang keseluruhnya mengacu pada kegunaan penelitian. Adapun saran-saran tersebut, sebagai berikut:

1. Sebagai warisan budaya dari nenek moyang mereka tentunya perlu dipertahankan mengingat terdapat nilai budaya yang masih mempertahankan khasnya.

2. Sebagai masukan untuk pemerintah untuk menciptakan suasana pemilihan yang berlangsung tertib, damai dan jujur.

\section{Daftar Pustaka}

Cangara, Hafield. 2007. Pengantar Ilmu Komunikasi. Jakarta: pt Raja grafindo Persada

Mulyana, Deddy. 2003. Metode Penelitian Kualitatif : Paradigma Baru Ilmu

Komunikasi dan Ilmu Sosial Lainnya. Remaja Rosdakarya

Mulyana, Deddy. 2001 a . Metode Penelitian Kualitatif. Bandung : Remaja

Rakhmat, Jalaludin. 2012. Psikologi Komunikasi.. Bandung: Rosdakarya Sihabudin , Ahmad.2011. Komunikasi Antar Budaya. Jakarta: Bumi Askara.

Suranto, Aw. (2010). Komunikasi Sosial Budaya. Cetakan pertama. Yogyakarta: Graha Ilmu. 